Tropical Journal of Pharmaceutical Research November 2018; 17 (11): 2183-2188

ISSN: $1596-5996$ (print); 1596-9827 (electronic)

(C) Pharmacotherapy Group, Faculty of Pharmacy, University of Benin, Benin City, 300001 Nigeria.

Available online at http://www.tjpr.org

Original Research Article

http://dx.doi.org/10.4314/tjpr.v17i11.11

\title{
Anticancer potential and cytotoxic effect of some freshwater cyanobacteria
}

\author{
Tunay Karan*, Ali Aydin \\ Department of Molecular Biology and Genetics, Faculty of Arts and Sciences, Gaziosmanpasa University, 60240 Tokat, Turkey
}

*For correspondence: Email: biyo_tunay@hotmail.com; Tel: +90 3562521616

Sent for review: 31 March 2018

Revised accepted: 25 October 2018

\begin{abstract}
Purpose: To investigate the anticancer potential and cytotoxicity of some freshwater cyanobacterial extracts on Human Colon Carcinoma (HT29), Rat Brain Glioma (C6), Human Cervix Carcinoma (HeLa), Human Lung Carcinoma (A549), Human Breast Adenocarcinoma (MCF7), Human Liver Hepatocellular Carcinoma (Hep3B) cancerous cells, African Green Monkey Kidney cells (Vero), and Human Amnion cells (FL).

Methods: Chroococus minutus, Geitlerinema carotinosum, Nostoc linckia and Anabaena oryzae were collected from different freshwater habitats and identified. Each cyanobacterium was extracted with methanol. Antiproliferative activities of the cyanobacterial extracts were evaluated by [3- $4,5-$ dimethylthiazolyl-2)-2,5-diphenyltetrazolium bromide] (MTT) using HT29, C6, HeLa, A549, MCF7, Hep3B, Vero, and FL cell lines. Cytotoxicity was determined by lactate dehydrogenase (LDH) assay.

Results: The cyanobacterial extracts showed varying antiproliferative and cytotoxic effects on cancer cells. G. carotinosum and N. linckia had significant inhibitory effect on C6 cell lines with half-maximal inhibitory ( $\left(C_{50}\right)$ levels of 112.69 and $121.48 \mu \mathrm{g} / \mathrm{mL}$, respectively. TGI values for G. carotinosum and $N$. linckia were 65.07 and $70.61 \mu \mathrm{g} / \mathrm{mL}$, respectively. $L C_{50}$ values for these two cyanobacteria were 386.64 and $760.55 \mu \mathrm{g} / \mathrm{mL}$, respectively. In addition, cyanobacterium $A$. oryzae displayed excellent antiproliferative effect on MCF7 cancer cells $\left(G I_{50}=2.04 \mu \mathrm{g} / \mathrm{mL}\right)$. The extracts displayed the cytostatic effect on the cell lines.
\end{abstract}

Conclusion: G. carotinosum, N. linckia and A. oryzae exhibit significant activity on various cancer cells. Hence these cyanobacteria may offer promise as anticancer agents.

Keywords: Freshwater cyanobacteria, Anticancer, Cytotoxicity, Chroococus minutus, Geitlerinema carotinosum, Nostoc linckia, Anabaena oryzae

\begin{abstract}
This is an Open Access article that uses a funding model which does not charge readers or their institutions for access and distributed under the terms of the Creative Commons Attribution License (http://creativecommons.org/licenses/by/4.0) and the Budapest Open Access Initiative (http://www.budapestopenaccessinitiative.org/read), which permit unrestricted use, distribution, and reproduction in any medium, provided the original work is properly credited.

Tropical Journal of Pharmaceutical Research is indexed by Science Citation Index (SciSearch), Scopus, International Pharmaceutical Abstract, Chemical Abstracts, Embase, Index Copernicus, EBSCO, African Index Medicus, JournalSeek, Journal Citation Reports/Science Edition, Directory of Open Access Journals (DOAJ), African Journal Online, Bioline International, Open-J-Gate and Pharmacy Abstracts
\end{abstract}

\section{INTRODUCTION}

Cyanobacteria, known as cyanoprokaryotes or blue-green bacteria, and gram negative prokaryotes are some of the oldest living forms in the world, dating back to 3.7 billion years $[1,2]$. The cyanobacteria have significant activities arising from production of some bioactive secondary metabolites [3]. Filamentous sea cyanobacteria have been reported to prevent cancer growth, neurodegenerative and infectious diseases [4]. Sea cyanobacteria include a great variety of compounds with pro-apoptotic effects [5]. Sea cyanobacteria Synechocystis sp. and 
Synechococcus sp. were reported to inhibit human promyeloctic leukemia (HL-60) cells [6]. Rise of cancer incidence and limitations of existing drugs make it desirable to develop new anticancer molecules from various sources including freshwater cyanobacteria [7]. It was reported that water extracts of Nostoc muscorum and Oscillatoria sp. showed high anticancer activity against Ehrlich Ascites Carcinoma cell and Human Hepatocellular (HepG2) cells [8]. In addition, aqueous extract of Spirulina sp. have been shown to inhibit Hepatic Stellate cell (HSC). Besides, crude extracts of six cyanobacteria (Phormidium sp., Geitlerinema sp., Arthrospira sp., Phormidium sp. Phromidium sp. and Leptolyngbya sp. demonstrated concentrationdependent inhibitions of Homo Sapiens Kidney Carcinoma and Homo Sapiens Colon Colorectral Adenocarcinoma [9]. Similarly, cyanobacterium Cyanothece sp. had high anticancer effect on extracellular T-lymphoma cells [10].

In the present study, anticancer properties of freshwater cyanobacteria species (Chroococcus minutus, Geitlerinema carotinosum, Nostoc linckia, Anabaena oryzae) were investigated on HeLa, HT29, A549, MCF7, Hep3B, C6 cancer cells and FL, Vero cells.

\section{EXPERIMENTAL}

\section{Isolation and culture of cyanobacteria}

Cyanobacteria were collected from freshwater habitats around Tokat Yesilirmak River. Collected and identified cyanobacteria were isolated mechanically under an inverted microscope. The cyanobacteria $C$. minutus and G. carotinosum were grown in a $250 \mathrm{ml}$ Erlenmeyer consisting of Bristol medium (125 $\mathrm{mL}$ ). N. linckia and $A$. oryzae were cultured in an Erlenmeyer vessel containing $125 \mathrm{ml}$ BG-11 medium [11]. The cells in the vessel were incubated under fluorescent lamp at $26 \pm 2{ }^{\circ} \mathrm{C}$ for 15 days. Then, cyanobacteria were centrifuged and dried at $60^{\circ} \mathrm{C}$.

\section{Cyanobacteria extraction}

Each dry cyanobacterium was extracted with methanol $(50 \mathrm{~mL})$ for $48 \mathrm{~h}$. The solvent was filtrated and then removed by rotary evaporator to yield the extract which was subsequently dissolved in dimethyl sulfoxide (DMSO) $(1.5 \mathrm{~mL})$ for storage at $4^{\circ} \mathrm{C}$ until use [12].

\section{Cell lines}

HeLa, MCF-7, Hep3B, A549, C6, HT29 cancer cell lines, along with $\mathrm{FL}$ cell and Vero kidney epithelial cell were used. Cell lines were incubated on a medium (Dulbecco's Modified Eagle Medium) enriched with 10\% fetal bovine serum and $2 \%$ penicillin Streptomycin at $37{ }^{\circ} \mathrm{C}$ and $5 \% \mathrm{CO}_{2}$ environment. Analyses were carried out after cells reached a certain density.

\section{MTT cell proliferation assay}

MTT test was used to evaluate the effects of extracts on cell proliferation [13]. After exposing cancer cells to the extracts for $24 \mathrm{~h}$, MTT test was performed.

A stock solution was prepared by mixing $5 \mathrm{mg} / \mathrm{ml}$ MTT solution with RPMl1640 medium (without phenol red). This new solution was added to the reaction medium with incubation for $4 \mathrm{~h}$. Absorbance measurement was carried out by a spectrophotometer at $560 \mathrm{~nm}$.

\section{Calculation of $\mathrm{GI}_{50}, \mathrm{TGI}, \mathrm{LC}_{50}$ and $\mathrm{IC}_{50}$ parameters}

At the end of incubation, cell inhibition was calculated. The half-maximal inhibitory concentration of the extracts $\left(\mathrm{IC}_{50}\right)$ and 5FU were calculated by XLfit5 software as in Eq 1 [14].

Inhibition $(\%)=\{(\mathrm{A}-\mathrm{B}) / \mathrm{B}\} \times 100$

where $A$ is the absorbance of the extracts and $B$ absorbance of untreated cells.

$\mathrm{Gl}_{50}$ (50 of \% Growth inhibition), TGI 50 (Total growth inhibition) and $\mathrm{LC}_{50}$ (50\% of drug causing cell kill) parameters were calculated for the extracts using Eqs 2 and 3.

$\mathrm{GI}_{50}=\{(\mathrm{Ti}-\mathrm{Tz}) /(\mathrm{C}-\mathrm{Tz})\} \times 100=50$ (provided that $\mathrm{Ti} \geq \mathrm{Tz}) \ldots \ldots . .(2)$

$\mathrm{TGI} \mathrm{Ti}=\mathrm{Tz} \ldots \ldots .(3)$

$50 \%$ of drug causing cell kill $\left(\mathrm{LC}_{50}\right)=\{(\mathrm{Ti}-\mathrm{Tz}) / \mathrm{Tz}\}$ $\times 100=-50($ provided that $\mathrm{Ti}<\mathrm{Tz}) . .(4)$

Here; Tz; zero point, C; control growth, Ti; inhibition of the test substance, TGl: Total growth inhibition [15].

\section{Determination of cytotoxic effects}

Lactate dehydrogenase (LDH) assay was carried out based on procedure provided by the manufacturer (Roche, USA). LDH activity was measured in terms of the amount of formazan produced. LDH activity was determined as absorbance at 492 - $630 \mathrm{~nm}$ by a microplate 
reader (RAYTO RT100C). Cytotoxic activity (T) was determined using Eq. 5 [14,15].

$\mathrm{T}(\%)=\{(\mathrm{EV}-\mathrm{LC} / \mathrm{HC}-\mathrm{LC})\} 100$

where EV = experimental value, $\mathrm{LC}=$ low control and $\mathrm{HC}=$ high control.

\section{Statistical analysis}

The experiments were performed in triplicate and all data are expressed as mean \pm standard deviation (SD). The data were analyzed by oneway ANOVA using SPSS software (version 21.0).

\section{RESULTS}

\section{Anticancer activity}

$\mathrm{GI}_{50}, \mathrm{TGI}, \mathrm{LC}_{50}$ and $\mathrm{IC}_{50}$ values of $C$. minutus and $G$. carotinosum were given in Table 1 . The antiproliferative activity of $N$. linckia and $A$. oryzae are shown in Table 2. Anticancer drug 5FU was used as a positive control (Table 3 ).

Compared with $\mathrm{IC}_{50}$ values of $5 \mathrm{FU}$ and cyanobacterial extracts, $G$. carotinosum and $N$. linckia showed better activity against $C 6$ cell lines $(112.69 \pm 0.07 \mu \mathrm{g} / \mathrm{mL}$ and $121.48 \pm 0.09 \mu \mathrm{g} / \mathrm{mL}$, respectively) than $5 \mathrm{FU}$ did (134.67 \pm 1.02 $\mu \mathrm{g} / \mathrm{mL}$ ).
Table 3: $\mathrm{Gl}_{50}, \mathrm{TGI}, \mathrm{LC}_{50}$, and $\mathrm{IC}_{50}$ values for $5 \mathrm{FU}$

\begin{tabular}{lcccc}
\hline \multirow{2}{*}{ Cell line } & \multicolumn{4}{c}{ 5FU } \\
\cline { 2 - 5 } & $\mathbf{G I}_{\mathbf{5 0}}$ & $\boldsymbol{T} \boldsymbol{T} \boldsymbol{I}$ & $\boldsymbol{L} \boldsymbol{C}_{\mathbf{5 0}}$ & $\boldsymbol{I C}_{\mathbf{5 0}}$ \\
\hline A549 & 13.34 & 63.25 & 763.06 & 83.62 \\
HeLa & 15.68 & 60.91 & 461.93 & 55.13 \\
Hep3B & 15.31 & 91.28 & $>1000$ & 161.13 \\
HT29 & 22.40 & 94.23 & 769.66 & 78.93 \\
MCF7 & 7.28 & 47.47 & $>1000$ & 48.42 \\
C6 & 21.82 & 102.72 & $>1000$ & 134.67 \\
Vero & 20.01 & 93.73 & 972.29 & 86.45 \\
FL & 21.23 & 82.36 & 582.62 & 138.38 \\
\hline
\end{tabular}

In terms of $50 \%$ growth inhibition parameter $\left(\mathrm{Gl}_{50}\right)$, C. minutus significantly inhibited growth of Hep3B and C6 cancer cells at $18-20 \mu \mathrm{g} / \mathrm{mL}$. It also inhibited the growth of MCF7 cells (3.31 \pm $1.02 \mu \mathrm{g} / \mathrm{mL})$ better than standard 5FU did (7.28 \pm $0.92 \mu \mathrm{g} / \mathrm{mL}$ ). $G$. carotinosum successfully inhibited growth of the MCF7 and C6 cells as well. $N$. linckia and $A$. oryzae extracts had a significant effect to inhibit MCF7, Hep3B and C6 cancer cell lines. Indeed, $A$. oryzae extract displayed the highest growth inhibition on MCF7 cells with a value of $2.04 \pm 0.32 \mu \mathrm{g} / \mathrm{mL}$.

G. carotinosum and $N$. linckia extracts inhibited total growth of the C6 cell at $65.07 \pm 0.23,70.61$ $\pm 0.45 \mu \mathrm{g} / \mathrm{mL}$, respectively, which were better than 5FU. A. oryzae also had an inhibition effect on $\mathrm{C} 6$ cell $(103.01 \pm 0.12 \mu \mathrm{g} / \mathrm{mL})$ close to $5 \mathrm{FU}$. A comparison with the standard (5FU) showed that the extracts had considerable levels of antiproliferative effects with potential to be used in pharmacology.

Table 1: $\mathrm{Gl}_{50}$, TGI, $\mathrm{LC}_{50}$ and $\mathrm{IC}_{50}$ for $C$. minutus and $\mathrm{G}$. carotinosum

\begin{tabular}{lcccc|cccc}
\hline \multirow{2}{*}{ Cell line } & \multicolumn{4}{c}{$\boldsymbol{C}$. minutus } & \multicolumn{4}{c}{ G. carotinosum } \\
\cline { 2 - 8 } & $\mathbf{G I}_{\mathbf{5 0}}$ & $\mathbf{T G}$ & $\mathbf{L} \mathbf{C}_{\mathbf{5 0}}$ & ${ }^{*} \mathbf{I}_{\mathbf{5 0}}$ & $\mathbf{G I}_{\mathbf{5 0}}$ & TGI & $\mathbf{L C}_{\mathbf{5 0}}$ & ${ }^{*} \mathbf{I}_{\mathbf{5 0}}$ \\
\hline A549 & 83.11 & $>1000$ & $>1000$ & 389.93 & 44.75 & $>1000$ & $>1000$ & 284.20 \\
HeLa & 35.95 & 752.93 & $>1000$ & 209.43 & 27.60 & 267.95 & $>1000$ & 170.74 \\
Hep3B & 19.81 & $>1000$ & $>1000$ & 296.15 & 21.77 & 801.54 & $>1000$ & 296.07 \\
HT29 & 240.77 & $>1000$ & $>1000$ & 367.78 & 89.93 & $>1000$ & $>1000$ & 330.17 \\
MCF7 & 3.31 & 253.69 & $>1000$ & 163.46 & 3.43 & 211.87 & $>1000$ & 148.58 \\
C6 & 18.61 & 136.08 & $>1000$ & 164.90 & 18.66 & 65.07 & 386.64 & 112.69 \\
Vero & 112.52 & $>1000$ & $>1000$ & 353.95 & 45.18 & 227.56 & $>1000$ & 144.97 \\
FL & 17.84 & 458.51 & $>1000$ & 274.44 & 20.10 & 189.01 & $>1000$ & 227.37 \\
\hline
\end{tabular}

${ }^{*}$ Linear equation was used

Table 2: $\mathrm{GI}_{50}, \mathrm{TGI}, \mathrm{LC}_{50}$ and $\mathrm{IC}_{50}$ for $N$. linckia and $A$. oryzae

\begin{tabular}{|c|c|c|c|c|c|c|c|c|}
\hline \multirow{2}{*}{ Cell line } & \multicolumn{4}{|c|}{ N. linckia } & \multicolumn{4}{|c|}{ A. oryzae } \\
\hline & $G I_{50}$ & TGI & $L C_{50}$ & ${ }^{\star} I C_{50}$ & $G I_{50}$ & TGI & $L C_{50}$ & ${ }^{\star} I C_{50}$ \\
\hline A549 & 143.60 & $>1000$ & $>1000$ & 370.84 & 248.92 & $>1000$ & $>1000$ & 407.95 \\
\hline HeLa & 18.38 & 214.06 & $>1000$ & 151.36 & 19.81 & 253.49 & $>1000$ & 168.38 \\
\hline Нер3В & 14.91 & 351.93 & $>1000$ & 245.93 & 13.29 & 575.72 & $>1000$ & 279.13 \\
\hline HT29 & 558.75 & $>1000$ & $>1000$ & 386.73 & 44.60 & 827.66 & $>1000$ & 180.82 \\
\hline MCF7 & 5.23 & 131.30 & $>1000$ & 133.16 & 2.04 & 394.94 & $>1000$ & 189.45 \\
\hline C6 & 15.36 & 70.61 & 760.55 & 121.48 & 11.71 & 103.01 & $>1000$ & 157.97 \\
\hline Vero & 79.85 & $>1000$ & $>1000$ & 214.99 & 41.43 & 500.42 & $>1000$ & 180.74 \\
\hline $\mathrm{FL}$ & 20.45 & 433.08 & $>1000$ & 284.24 & 25.97 & 584.10 & $>1000$ & 290.24 \\
\hline
\end{tabular}




\section{Lactate dehydrogenase (LDH) release}

The cytotoxic effects caused by extracts in the present study was determined by measuring $\mathrm{LDH}$ at various concentrations $(15,30,60$ and $120 \mu \mathrm{g} / \mathrm{mL}$ ) (Figure 1). Cyanobacterial extracts showed low cytotoxicity at all concentrations on HeLa and A549 cell lines $(\sim 10-20 \%$ cytotoxicity). It has been found that at low concentrations, the cytotoxic effect of the extracts on MCF7 cell line was very low and increased along with the concentration $(\sim 5-40$ $\%$ cytotoxicity). As in MCF7 and the Hep3B cell line, the toxicity was low at low concentrations. The extracts were found to be more toxic on other cell lines (HT29, C6, FL). C. minutus and A. oryzae had low cytotoxic effects on Vero cell lines, but their cytotoxicities were high in other extracts. Compared to standard 5FU whose cytotoxicity is known to be $5-15 \%$, the extracts were found to have cytostatic effects on HeLa, A549, MCF7 and Hep3B cells. Because of their low toxicity and high antiproliferative effects, the extracts examined in the present study are suitable for drug development and they merit more advanced pharmacological investigations.

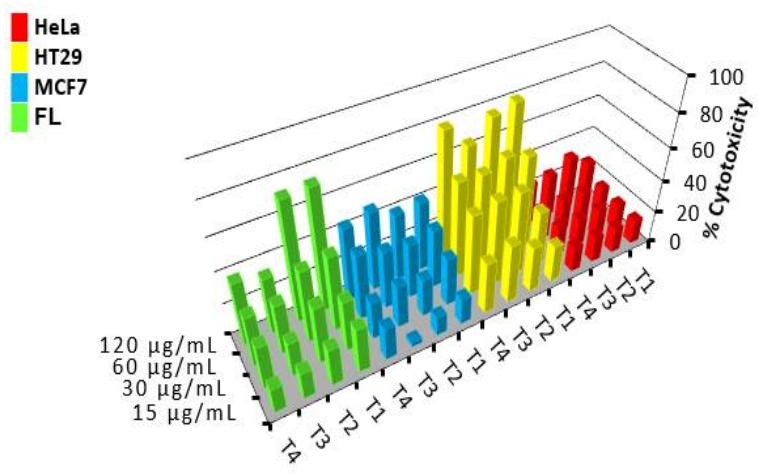

A

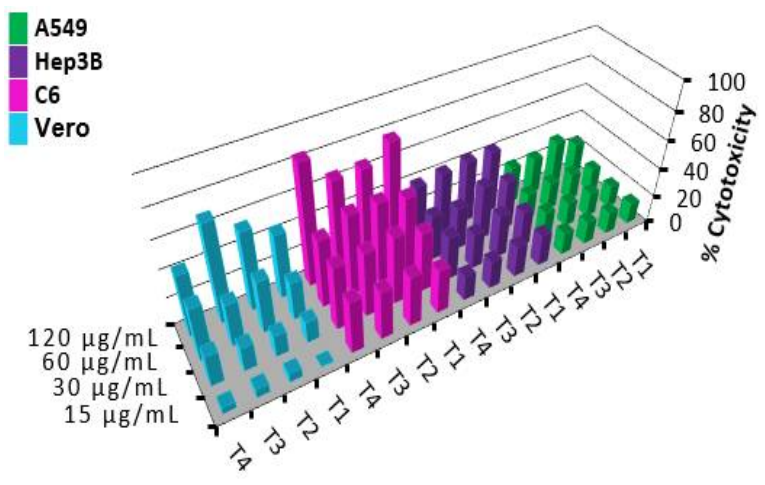

B

Figure 1: The cytotoxic activities of cyanobacterial extracts on HeLa, HT29, MCF7 and FL (A), and A549, Hep3B, C6 and Vero (B) cells. T1: Chroococus minutus, T2: Geitlerinema carotinosum, T3: Nostoc linckia, T4: Anabaena oryzae

\section{Morphological correlation with cytotoxic activity}

Morphological changes caused by high anticancer activity of the $G$. carotinosum extract on $\mathrm{C} 6$ cell and low cytotoxicity on the HeLa cell were examined by inverse phase-contrast microscopy (Figure 2).
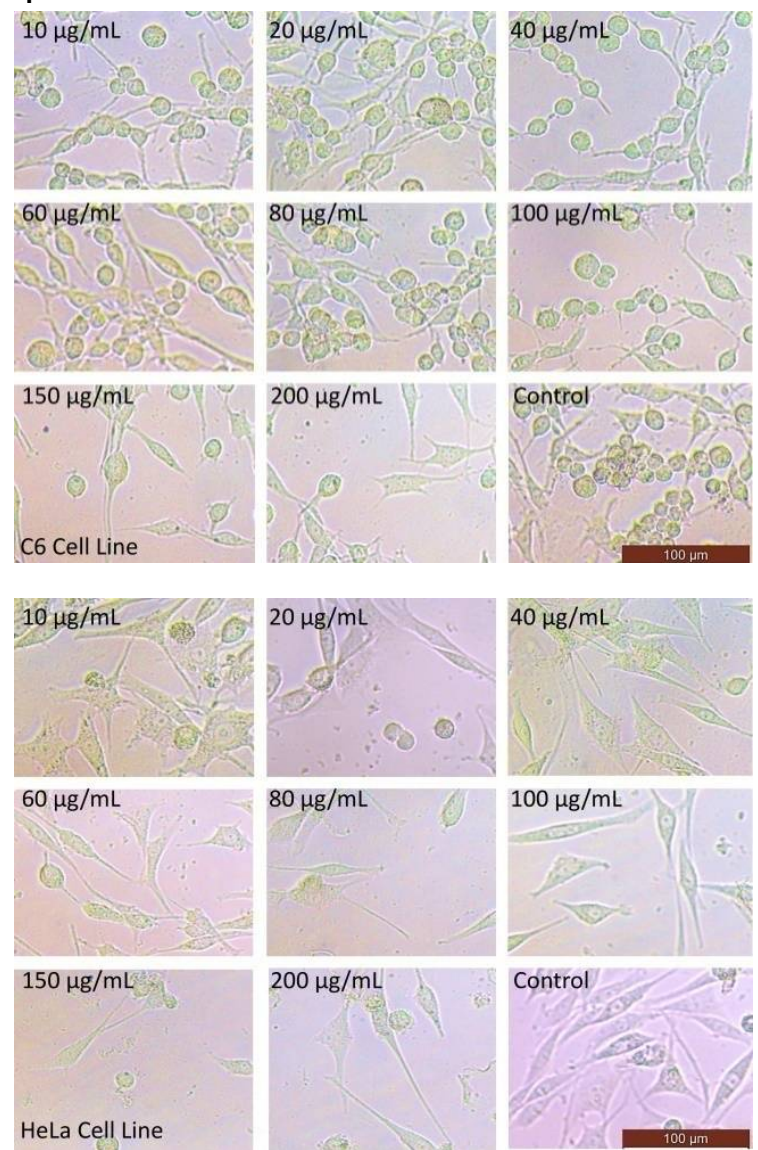

Figure 2: Effect of $G$. carotinosum extract on morphology of C6 and HeLa cells. DMSO-treated cells are controls

\section{DISCUSSION}

Cyanobacteria are oxygen producing organisms and they can live almost everywhere. They are a source of rich bioactive natural products [16]. The medical value of cyanobacteria has been known for a long time. Indeed, some cyanobacteria have been used for the treatment of some illnesses such as gout, fistula and various types of cancer $[17,18]$. Aqueous extract of Spirulina platensis was reported to inhibit growth of Human Pancreatic Adenocarcinoma (PA-TU-8902) [19]. Similarly, Phormidium sp. was shown to inhibit the growth of HT29 and HeLa cells [20,21].

Due to the increasing cancer incidence in the world and high level of side effects by commonly 
used chemotherapy drugs, there has been an interest in use of natural products in cancer treatment recently. In the present study, antiproliferation and cytotoxicity features of cyanobacteria were examined on various cell lines to reveal their anticancer potential. Of the cyanobacteria studied, G. carotinosum showed the highest anticancer activity. It has been reported that anticancer effects of single filament cyanobacteria are high [22]. Similarly, Geitlerinema sp. CCC728 and Arthrospira sp. CCC729 were considered to be potent anticancer drug sources [9]. In addition, the LC $_{50}$ is important in cancer research and the fact that the LC50 is low indicates the high activity of cancer cells [23].

LDH assay in culture medium is used as an indicator for cytotoxicity [24]. Lactate dehydrogenase is a cytoplasmic enzyme found in all cells. When cells are exposed to toxic effects, plasma membrane integrity is impaired and LDH enzyme penetrates into cells. Thus, cell damage can be assessed by measuring LDH activity after exposure to toxic effects [25]. In the present study, some of the cyanobacterial extracts displayed considerable antiproliferative activities on various cancer cell lines, and they did not have any cytotoxicity on FL (human amnion cells) and Vero (kidney epithelial cell) cells. Thus, these extracts have the potential to be used in pharmacology.

Apoptosis leads to characteristic changes (morphology) and death of cells [26]. Cyanobacterial extracts have been found to contain long acting apoptotic compounds [10]. Research demonstrated that Oscillatoria terebriformis extract reduced cell viability of Human Lung Cancer Cell Lines by induction of apoptosis [27]. It was observed that Spirulina sp. extract enriched with selenium inhibited the growth of breast cancer cells via induction of apoptosis [28]. Their ease of culturing and promising anticancer activities make cyanobacteria particularly attractive organisms for drug development through future biotechnological studies.

\section{CONCLUSION}

G. carotinosum, N. linckia and $A$. oryzae display considerable activity against various cancer cells. Therefore, these cyanobacteria merit investigation as part of a drug discovery process. The bioactive secondary metabolites should be isolated and identified from corresponding cyanobacteria to determine activity-compound interactions.

\section{DECLARATIONS}

\section{Acknowledgement}

The author is grateful to Dr Ramazan ERENLER for providing laboratory facilities and also to $\mathrm{Dr}$ Nejdet Kandemir for editing the manuscript.

\section{Conflict of Interest}

No conflict of interest associated with this work.

\section{Contribution of Authors}

The authors declare that this work was done by the authors named in this article and all liabilities pertaining to claims relating to the content of this article will be borne by them.

\section{REFERENCES}

1. Berman-Frank I, Lundgren $P$, Chen $Y$-B, Küpper $H$, Kolber $Z$, Bergman B, Falkowski $P$. Segregation of nitrogen fixation and oxygenic photosynthesis in the marine cyanobacterium Trichodesmium. Sci 2001; 294(5546): 1534-1537.

2. Lee RE, Phycology. Cambridge University Press, 2008.

3. Nagarajan M, Maruthanayagam V, Sundararaman M. A review of pharmacological and toxicological potentials of marine cyanobacterial metabolites. J Apply Toxicol 2012; 32(3): 153-185.

4. Tan LT. Pharmaceutical agents from filamentous marine cyanobacteria. Drug discovery today 2013; 18(17): 863871.

5. Costa M, Costa-Rodrigues J, Fernandes MH, Barros $P$, Vasconcelos $V$, Martins $R$. Marine cyanobacteria compounds with anticancer properties: A review on the implication of apoptosis. Marine drugs 2012; 10(10): 2181-2207.

6. Martins RF, Ramos MF, Herfindal L, Sousa JA, Skærven $K$, Vasconcelos VM. Antimicrobial and cytotoxic assessment of marine cyanobacteria-Synechocystis and Synechococcus. Marine drugs 2008; 6(1): 1-11.

7. Tan LT. Filamentous tropical marine cyanobacteria: a rich source of natural products for anticancer drug discovery. J Apply Toxicol 2010; 22(5): 659-676.

8. Shanab SM, Mostafa SS, Shalaby EA, Mahmoud GI. Aqueous extracts of microalgae exhibit antioxidant and anticancer activities. Asian Pac J Trop Biomed 2012; 2(8): 608-615.

9. Srivastava A, Tiwari R, Srivastava V, Singh TB, Asthana RK. Fresh water cyanobacteria Geitlerinema sp. CCC728 and Arthrospira sp. CCC729 as an anticancer drug resource. PloS one 2015; 10(9): e0136838.

10. Oftedal L, Skjærven $K H$, Coyne RT, Edvardsen B, Rohrlack T, Skulberg OM, Døskeland SO, Herfindal L. The apoptosis-inducing activity towards leukemia and lymphoma cells in a cyanobacterial culture collection is

Trop J Pharm Res, November 2018; 17(11): 2187 
not associated with mouse bioassay toxicity. J Ind Microbiol Biotechnol 2011; 38(4): 489-501.

11. Karan T, Erenler R, Altuner Z. Isolation and Molecular Identification of Some Blue-Green Algae (Cyanobacteria) from Freshwater Sites in Tokat Province of Turkey. Turk J Agricult Food Sci Technol 2017; 5(11): 1371-1378.

12. El Sadek DAA, Hamouda RA, Bassiouny $K$, Elharoun $H$. In vitro Antioxidant and Anticancer Activity of Cyanobacteria. Asian J Med Health 2017; 6(3): 1-9.

13. Mosmann T. Rapid colorimetric assay for cellular growth and survival: application to proliferation and cytotoxicity assays. J Immunol Methods 1983; 65(1-2): 55-63.

14. Karan T, Yildiz I, Aydin A, Erenler R. Inhibition of Various Cancer Cells Proliferation of Bornyl Acetate and Essential Oil from Inula graveolens (Linnaeus) Desf. Rec Nat Prod 2018; 12(3): 273-283.

15. Suja M, Vasuki S, Sajitha N. Anticancer activity of compounds isolated from marine endophytic fungus Aspergillus terreus. World J Pharm Pharm Sci 2014; 3: 661-672.

16. Sivonen K, Börner T. Bioactive compounds produced by cyanobacteria. The cyanobacteria: molecular biology, genomics and evolution 2008: 159-197.

17. Burja AM, Banaigs B, Abou-Mansour E, Burgess JG, Wright PC. Marine cyanobacteria-a prolific source of natural products. Tetrahedron 2001; 57(46): 9347-9377.

18. Shalaby E. Algae as promising organisms for environment and health. Plant Signal Behav 2011; 6(9): 1338-1350.

19. Konícčková R, Vanňková K, Vaníková J, Vánňová K, Muchová L, Subhanová I, Zadinová M, Zelenka J, Dvorrák $A$, Kolárr $M$. Anti-cancer effects of blue-green alga Spirulina platensis, a natural source of bilirubin-like tetrapyrrolic compounds. Annals of Hepatology 2014; 13(2): 273-283.

20. Salvador LA, Paul VJ, Luesch H. Caylobolide B, a macrolactone from symplostatin 1-producing marine cyanobacteria Phormidium spp. from Florida. J Nat Prod 2010; 73(9): 1606-1609.

21. Tokur O, Aksoy A. In Vitro Sitotoksisite Testleri. Harran Univ Vet Fak Derg 2017; 6(1); 112-118.

22. Costa M, Garcia M, Costa-Rodrigues J, Costa MS, Ribeiro MJ, Fernandes $M H$, Barros $P$, Barreiro $A$, Vasconcelos $V$, Martins $R$. Exploring bioactive properties of marine cyanobacteria isolated from the Portuguese coast: high potential as a source of anticancer compounds. Marine drugs 2013; 12(1): 98114.

23. Al-Saadi MS, Rostom SA, Faid-Allah HM. In vitro antitumor screening of some polysubstituted pyrazole analogs. Saudi Pharm J 2005; 13: 89-96.

24. Johnson JJ, Mukhtar H. Curcumin for chemoprevention of colon cancer. Cancer letters 2007; 255(2): 170-181.

25. Niles AL, Moravec RA, Hesselberth PE, Scurria MA, Daily WJ, Riss TL. A homogeneous assay to measure live and dead cells in the same sample by detecting different protease markers. Anal Biochem 2007; 366(2): 197-206.

26. Akşit H, Bildik A. Apoptozis. YYU Vet Fak Derg 2008; 19(1): 55-63.

27. Mukund S, Sivasubramanian V. Anticancer Activity of Oscillatoria Terebriformis Cyanobacteria in Human Lung Cancer Cell Line A549. 2014.

28. Chen T, Wong Y-S. Selenocystine induces S-phase arrest and apoptosis in human breast adenocarcinoma MCF-7 cells by modulating ERK and Akt phosphorylation. J Agric Food Chem 2008; 56(22): 10574-10581. 